\title{
Beyond the stained back-drop
}

\author{
Lovely Chhabra, ${ }^{1}$ Saurabh Joshi, ${ }^{1}$ Renu Goyal, ${ }^{1}$ Gerald T Mcgillicuddy ${ }^{2}$
}

${ }^{1}$ Department of Internal Medicine, Saint Vincent Hospital, University of

Massachusetts Medical School, Worcester, Massachusetts, USA

${ }^{2}$ Department of Neurosurgery, Saint Vincent Hospital, University of Massachusetts Medical School, Worcester, Massachusetts, USA

\section{Correspondence to} Dr Lovely Chhabra, lovids@hotmail.com
To cite: Chhabra L, Joshi S, Goyal R, et al. BMJ Case Rep Published online:

[please include Day Month Year] doi:10.1136/bcr-2013010449

\section{DESCRIPTION}

A 63-year-old-man presented to hospital with progressive low-back pain over the last 3 months. He also reported weight loss of $30 \mathrm{lbs}$ in last 3 months. MRI of lower spine revealed $1 \mathrm{~cm}$ left-sided intradural
A

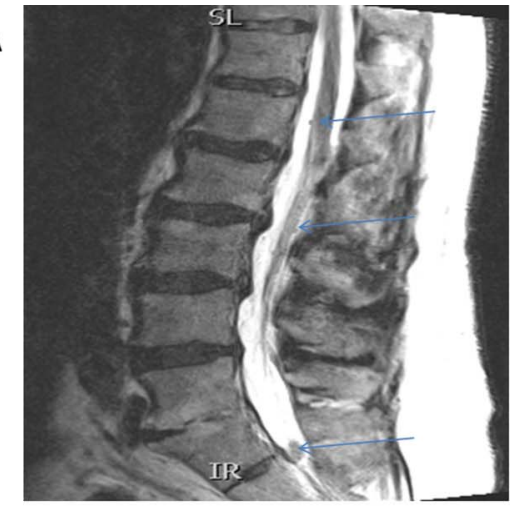

C

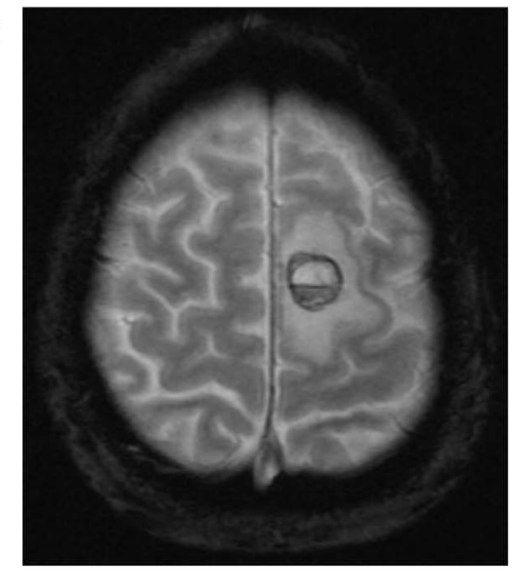

E

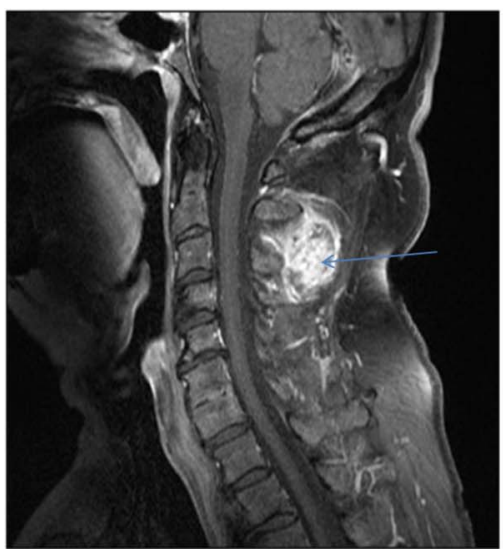

extramedullary enhancing lesion at S1-level, with mass effect on the thecal sac (figure 1A,B). Given the clinical history and location of the lesion, MRI of the entire spine (cervical, thoracic and lumbosacral region), and brain were ordered to rule out drop

B

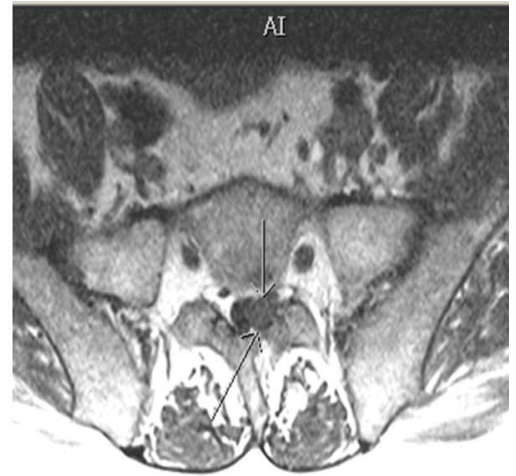

D

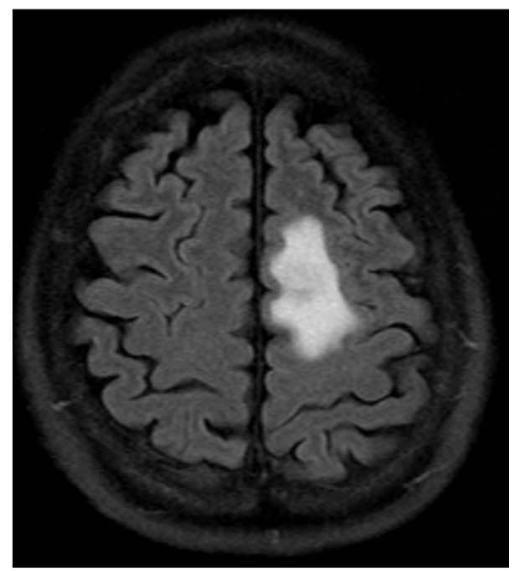

$\mathbf{F}$

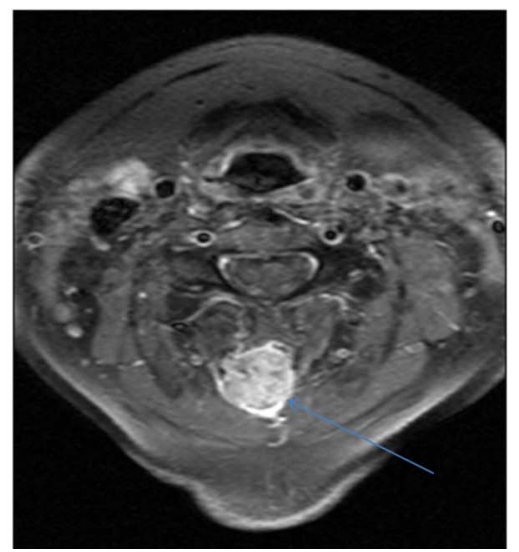

Figure 1 (A) MRI of lower spine - saggital view reveals beads of Drop-metastasis. There is $1 \mathrm{~cm}$ intradural extramedullary enhancing lesion at S1-level, with mass effect on the thecal sac (marked by arrow). Several smaller nodules can also be seen across lumbar spinal column (marked by arrows). (B) MRI of lower spine-axial view at S1-level reveals $1 \mathrm{~cm}$ left-sided intradural extramedullary enhancing lesion as shown earlier. (C) and (D) Brain MRI shows a large enhancing mixed signal intensity lesion. (C) clearly reveals a ring enhancement in the paramedian convexity of the left frontal lobe (maximum diameter $1.4 \mathrm{~cm}$ ), with a fluid level suggestive of associated haemorrhage, a tendency of melanoma. (E) and (F) Cervical spine MRI (saggital and axial views respectively): show a soft tissue enhancing mass in the posterior soft tissues of the neck in the midline and extending within the interspinous space, with maximum diameter of $3.1 \mathrm{~cm}$. 


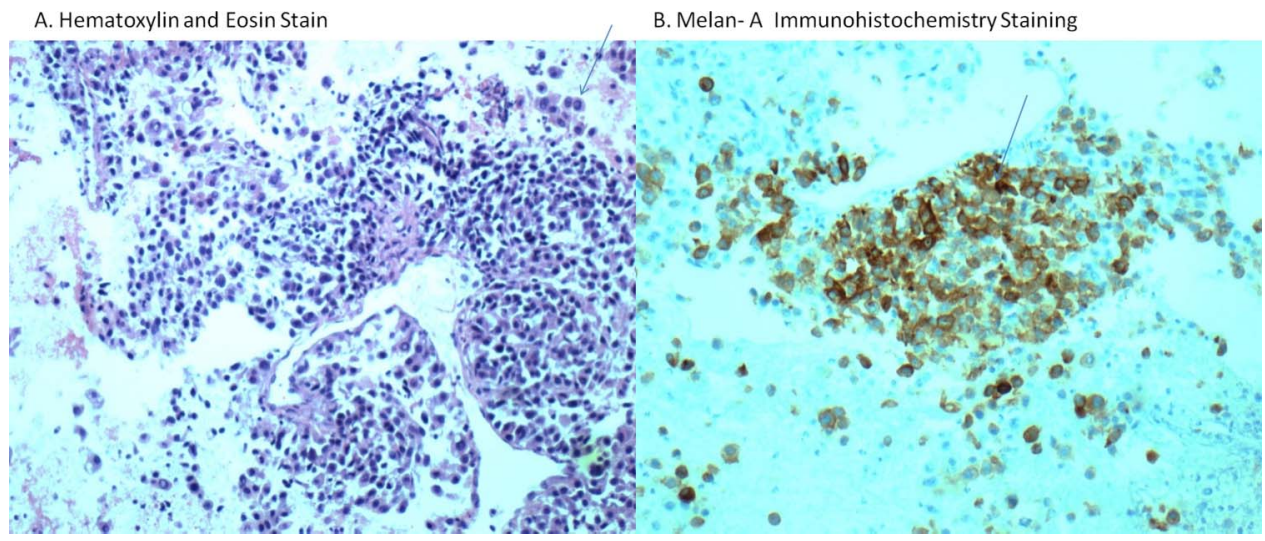

Figure 2 (A) Histopathology reveal some hyperchromatic cells with vacuolated nuclei (marked by arrow). (B) Immunohistochemistry staining is positive with Melan-A suggesting malignant melanoma.

metastasis. Brain MRI showed ring enhancing lesion with a fluid level in the left frontal lobe (figure 1C,D). Cervical spine MRI revealed a midline soft tissue enhancing mass (figure 1E,F). Brain lesion and cervical soft tissue mass were excised surgically. Histopathology revealed hyperchromatic cells with vacuolated nuclei and immunochemistry staining was positive for S-100 and Melan-A, diagnostic for melanoma (figure 2A,B). Extensive workup including contrast enhanced CT-scan of the chest,

\section{Learning points}

- Drop metastases refers to spinal metastases that arise from intracranial lesions. High suspicion should be raised especially if a spinal lesion is seen in the intradural extramedullary location and thus appropriate further diagnostic work-up should be pursued, including Pan-MRI of the spine and the brain.

- Tissue manipulation resulting from neurosurgical interventions can enhance the likelihood of drop metastases, though it can occur in patients without prior history of any surgical intervention.

- Depending on the size, location and number of drop metastases, the management may include neurosurgery, radiation and steroid therapy. The long-term prognosis of such patients is however often poor. abdomen and pelvis, positron emission tomography scan, rectal exam and thorough skin exam revealed no evidence of other primary tumour site and history was negative for any prior skin melanoma. Genetic analysis showed V600E BRAF mutation. Patient received radiotherapy and Vemurafenib, and is clinically doing well.

Intradural extramedullary spinal metastases that arise from intracranial lesions are called 'Drop Metastases'. ${ }^{1}$ The mechanism of spread is likely via cerebrospinal fluid when the tumour reaches and exfoliates cells into the subarachnoid space, and because of gravitational effects, the lesions may occur at multiple places across the spinal column. ${ }^{1}{ }^{2}$ Our case represents metastatic malignant melanoma associated with spinal drop metastasis resulting from the intracranial secondary. A diligent multidisciplinary team, neuroimaging characteristics and pathology staining enabled us to go beyond a common symptomback pain.

Contributors All authors have participated in writing the manuscript and reviewing the literature involved. All authors have reviewed the manuscript before submission and have approved it.

\section{Competing interests None.}

Patient consent Obtained.

Provenance and peer review Not commissioned; externally peer reviewed.

\section{REFERENCES}

1 Choi PP, Shapera S. What's your call? Drop metastases. CMAJ 2006;175:475-7.

2 Rao AJ, Gultekin SH, Neuwelt EA, et al. Late occurrence of drop metastasis to the spine in a case of esthesioneuroblastoma. J Neurosurg Spine 2011;15:571-5.

Copyright 2013 BMJ Publishing Group. All rights reserved. For permission to reuse any of this content visit http://group.bmj.com/group/rights-licensing/permissions.

BMJ Case Report Fellows may re-use this article for personal use and teaching without any further permission.

Become a Fellow of BMJ Case Reports today and you can:

- Submit as many cases as you like

- Enjoy fast sympathetic peer review and rapid publication of accepted articles

- Access all the published articles

- Re-use any of the published material for personal use and teaching without further permission

For information on Institutional Fellowships contact consortiasales@bmjgroup.com

Visit casereports.bmj.com for more articles like this and to become a Fellow 